\title{
СПІВПРАЦЯ УКРАЇНИ В МІЖНАРОДНІЙ СИСТЕМІ ЗАПОБІГАННЯ ЗЛОЧИННОСТІ
}

Дідківська Г. В.

Сучасні процеси всесвітньої інтеграції, які стрімко розвиваються у XXI cm., відобразилися у більшості соціально-політичних і економічних явищ та процесів на всіх рівнях - внутрішньодержавному, регіональному, світо вому. Зазначається, що загальносоціальна система запобігання злочинності містить у собі комплекс перспективних організаційно-правових, соціально-економічних і культурно-виховних заходів, спрямованих на подальший розвиток і вдосконалення міжнародної співпраці, усунення або нейтралізацію причин та умов злочинності.

Вказується, що вирішальна роль у поступовому зменшенні суперечностей участі в міжнародній системі запобігання злочинності покладається на діяльність усіх державних органів, підприємств, установ, фірм, громадських організацій. Потенціал цієї діяльності полягає в тому, що вона запобігає негативним явищам і процесам, які сприяють відтворенню або збільшенню рівня злочинів, стимулює дотримання законів і міжнародних угод державами.

Ключові слова: злочин, злочинність, запобігання, міжнародна співпрачя, система, причини, умови, рівень, правоохоронні органи.

Современные процессы всемирной интеграции, которые стремительно развиваются в XXI веке, отразились в большинстве социально-политических и экономических явлений и процессов на всех уровнях - внутригосударственном, региональном, мировом. Отмечается, что общесоциальная система предупреждения преступности включает в себя комплекс перспективных организационно-правовых, социально-экономических и культурно-воспитательных мероприятий, направленных на дальнейшее развитие исовершенствованиемеждународногосотрудничества, устра нение или нейтрализацию причин и условий преступности.

Указывается, что решающая роль в постепенном уменьшении противоречий участию в международной системе предупреждения преступности возлагается на деятельность всех государственных органов, предприятий, учреждений, фирм, общественных организаций. Мера потенциала этой деятельности заключается в том, что она предотвращает негативные явления и процессы, которые способствуют восстановлению или увеличению уровня преступлений, стимулирует соблюдение законов и международных соглашений государствами.

Ключевые слова: преступление, преступность, предупреждение, международное сотрудничество, система, причины, условия, уровень, правоохранительные органы.

Modern processes of world integration, which are rapidly developing in the twenty-first century, have been reflected in most socio-political and economic phenomena and processes at all levels - domestic, regional and world. It is noted that the general social system of crime prevention includes a set of promising organizational, legal, socio-economic, cultural and educational measures aimed at further developing and improving international cooperation and eliminating or neutralizing at the same time the causes and conditions of crime.

Дідківська Г. В., 2019
It is stated that the activities of all State bodies, enterprises, institutions, firms and public organizations play a decisive role in gradually reducing the contradictions of participation in the international crime prevention system. The precautionary measures of this activity are that it prevents negative phenomena and processes that contribute to the restoration or increase of crimes, encourages compliance with laws and international agreements by States.

It is stated that the international crime prevention system is a system based on the generally recognized legal framework and harmonized national legislation of each State Party, which includes a well-established system of prevention actors at all levels and directions of this activity based on the singularity of goals and objectives, forms and methods. Ukraine's international cooperation focuses on the prevention of crime, in particular its transnational manifestations (illicit trafficking in drugs, arms, stolen motor vehicles, trafficking in persons, etc.); peacekeeping activity; Exchange of experience, training, research; loans of the international experience; Involvement of international organizations in the implementation of law enforcement reform programmes in Ukraine.

A reliable guarantee of the proper functioning of the European area of justice, freedom and security (creating conditions for effective international law enforcement) is to ensure the necessary level of law and order not only in the territory of each individual State, but also in all States as a whole.

Key words: crime, crime, prevention, international cooperation, system, reasons, conditions, level, law enforcement agencies.

Постановка проблеми та їі актуальність. Натепер у кримінології все частіше вказують на необхідність посилення орієнтації суспільства на зберігання традиційних духовних і гуманістичних цінностей, переорієнтацію державної політики з репресивних форм впливу на злочинність на створення передумов для зміцнення в суспільстві загальнолюдських цінностей, що дозволить вийти на шлях реального зниження рівня злочинності.

Тому актуальною залишається проблема розробки та впровадження стратегічних кримінологічно-виважених програм запобігання злочинності, які повинні будуватися на науково обґрунтованих прогнозах основних тенденцій злочинності й враховувати національно-історичний та міжнародний досвід запобігання злочинності. Це можуть бути спільні міждержавні програми, нормативно-правові акти з регламентації спільних заходів запобігання злочинності.

Виклад основного матеріалу. На думку автора, міжнародна система запобігання злочинності - це система, заснована на загальновизнаній договірно-правовій базі та уніфікованому національному законодавстві кожної держави-учасниці, що включає налагоджену систему суб'єктів запобігання на всіх рівнях i напрямах цієї діяльності і ґрунтується на єдності цілей i завдань, форм і методів. Міжнародне співробітництво України здійснюється за такими основними напрямами як запо- 
бігання злочинності, зокрема її транснаціональним проявам (незаконний обіг наркотиків, зброї, викраденого автотранспорту, торгівля людьми тощо); миротворча діяльність; обмін досвідом, підготовка кадрів, проведення наукових досліджень; запозичення міжнародного досвіду; залучення міжнародних організацій до реалізації програм реформування правоохоронних органів України.

Слід зазначити, що з часу здобуття Україною незалежності правоохоронні органи України налагоджували та розвивали міжнародне співробітництво у боротьбі зі злочинністю, зокрема у контексті реалізації політики загальноєвропейської безпеки та боротьби зі злочинністю, серед ключових євроінтеграційних завдань, які належать до компетенції правоохоронних органів України і потребують якнайшвидшого розв'язання проблем щодо узгодженості дій при здійсненні заходів запобігання злочинності, а також вжиття ефективних заходів щодо попередження та протидії нелегальній міграції.

Сучасна злочинність стає все більш мобільною i діяльною, чому сприяє посилення інтенсивності міграційних процесів, лібералізація режиму перетину державних кордонів, використання правопорушниками новітніх телекомунікаційних, інформаційних, транспортних, банківських та інших технологій, які дозволяють зазіхати на охоронювані законом об'єкти «дистанційно» (перебуваючи за межами держави, на території якої заподіюється злочинна діяльність). Зростає кількість організованих транснаціональних злочинних об'єднань. Все більша кількість злочинних практик (торгівля людьми, незаконні дії в сфері трансплантології, незаконний обіг психоактивних речовин, контрабанда, продаж зброї і боєприпасів, внутрішній і міжнародний тероризм, злочини у сфері інформаційних технологій та інтелектуальної власності, міжнародна корупція, легалізація здобутого злочинним шляхом майна, переміщення екологічно небезпечних речовин з одних держав до інших, угони транспортних засобів із реалізацією їх за межами країни, викрадення предметів мистецтва й міжнародна нелегальна торгівля ними тощо) характеризуються як «міжнародний компонент».

Серед чинників, які актуалізують потребу участі України в міжнародній системі запобігання злочинності, слід згадати й те, що певна частина правопорушників завжди намагається ухилитися від відповідальності за вчинене, сховавшись у країнах, які не були місцем їхнього злочину. Чимало злочинців залишає Україну, переховуючись від вітчизняних правоохоронних органів, а територія України іноді стає місцем переховування злочинців, які втекли від органів правосуддя іншої держави.

На думку автора, умови сучасного світу вимагають, щоб між державами встановилися, крім просто мирного співіснування, нові відносини співпраці як регіональні, так навіть і всесвітні». Сьогодні можна говорити про те, що еволюція злочинності об'єктивно створила передумови до взаємозалежності і солідарності держав у реалізації кримінальної політики, Україна (як і будьяка інша держава, яка поважає міжнародне право) має досить обмежені можливості у протидії кримінальним загрозам, які формуються й реалізуються на різних державних територіях.

Вітчизняні органи влади під час здійснення кримінального провадження у процесі реалізації криміналь- ної відповідальності мають повноваження, окреслені межами внутрішньої (національної) кримінально-правової юрисдикції. Зважаючи на необхідність дотримання засад поваги державного суверенітету інших держав їхні працівники не можуть (і не мають права), керуючись внутрішнім законодавством України, виконувати на території іноземної держави дії, спрямовані на охорону правопорядку, розкриття злочинів, збирання доказів, затримання осіб, застосування покарань тощо.

Перелічені вище чинники виводять проблеми організації реагування на злочини за межі внутрішніх інтересів нашої держави та вимагають від України вживати адекватні змінам криміногенної картини світу заходи як на рівні національної правової системи, так і на міжнародно-правовому рівні. В таких умовах все більш актуальними стають питання розвитку міжнародної співпраці України в сфері запобігання злочинності. Це завдання мають спільно вирішувати всі суб'єкти владних повноважень як ті, які відповідають за нормативне забезпечення кримінально-правової політики України (парламент держави), так i ті, що здійснюють іï практичну реалізацію (вітчизняні органи кримінальної юстиції).

У зв'язку з появою у XX - XXI ст. нових форм злочинної діяльності, а також можливостей злочинців переховуватися від правосуддя виникла нагальна необхідність об'єднання зусиль усіх країн світу з метою створення нових форм взаємовигідної співпраці держав у сфері кримінального судочинства. Міжнародна співпраця у сфері запобігання злочинності здійснюється у різних напрямах, у певних формах і видах.

Проаналізовано існуючі напрями міжнародної співпраці у боротьбі зі злочинністю як шляхи розвитку, як певні течії у цьому розвитку: спонукання держав і сприяння в укладанні угод у сфері запобігання злочинності та поводження з фізичними особами, які порушили норми цих угод; розробку міжнародних стандартів щодо запобігання злочинності, кримінального переслідування і відбування покарання за вчинення міжнародних злочинів і злочинів міжнародного характеру; розробку рекомендацій для боротьби національних правоохоронних органів із загально-кримінальними злочинами, інформаційну та консультаційну допомогу державам (3 урахуванням того, що кожна держава веде цю боротьбу в рамках суверенітету, у межах своєї території та відповідно до власних соціальних та економічних умов).

Міжнародна співпраця у сфері запобігання злочинності може здійснюватися в таких основних формах: надання взаємної правової допомоги з кримінальних справ; видача фізичних осіб, які вчинили злочини, для притягнення до кримінальної відповідальності або виконання вироку; передача засуджених до позбавлення волі для подальшого відбування покарання у державі їх громадянства або постійного місця проживання; обмін оперативною, правовою або іншою інформацією; виконання доручень з міжнародного розслідування; забезпечення прав і свобод громадян певної держави при здійсненні кримінального правосуддя в іншій державі; підготовка кадрів, обмін досвідом роботи правоохоронних органів різних держав у боротьбі з міжнародною злочинністю; надання експертних і консультативних послуг, спеціальних науково-технічних засобів і здійснення іншої матеріально-технічної допомоги; спільне вивчення проблем злочинності та боротьби з нею, прогнозування та програмування цієї діяльності; участь 
в офіційних заходах (конгресах, нарадах) і науково-технічних конференціях (семінарах, симпозіумах), де обговорюють проблеми міжнародного співробітництва у запобіганні злочинності.

Враховуючи те, що Україна стала об'єктом зростаючої зацікавленості міжнародних злочинних угруповань (зокрема у сферах відмивання «брудних» грошей, незаконної міграції, торгівлі людьми, зброєю, небезпечними матеріалами, наркотичними речовинами тощо), то вирішення Україною важливих соціально-економічних, політичних та інших завдань практично не можливе без iї участі в міжнародному співробітництві в боротьбі зі злочинністю, в діяльності міжнародних правоохоронних організацій. 3 огляду на це участь нашої держави у міжнародній співпраці у галузі протидії злочинності на основі норм і принципів міжнародного права $є$ досить важливою. Цілком зрозуміло, що таке співробітництво України з країнами світу, міжнародними організаціями $\epsilon$ вагомою умовою успішного вирішення багатьох проблем не лише зовнішньополітичного, зовнішньоекономічного, а й внутрішнього характеру.

Серед чинників, які актуалізують потребу у взаємодії суверенних суб'єктів міжнародних відносин у протистоянні злочинності, слід згадати й те, що певна частина правопорушників завжди намагається ухилитися від відповідальності за вчинене ними, сховавшись у країнах, які не були місцем їхнього злочину. Чимало злочинців залишає Україну, переховуючись від вітчизняних правоохоронних органів, а територія України іноді стає місцем переховування злочинців, які втекли від органів правосуддя іншої держави. «Умови сучасного світу, - писав Рене Давид, - вимагають, щоб між державами встановилися, крім просто мирного співіснування, нові відносини співпраці як регіональні, так навіть і всесвітні» $[1$, с. 9].

Натепер можна говорити про те, що еволюція злочинності об'єктивно створила передумови до взаємозалежності і солідарності держав у реалізації кримінальної політики [2, с. 24-26]. Україна (як і будь-яка інша держава, яка поважає міжнародне право) має досить обмежені можливості у протидії кримінальним загрозам, що формуються й реалізуються на різних державних територіях (транскордонній, транснаціональній злочинності, злочинам, які мають регіональний, наднаціональний чи транснаціональний елементи).

Вітчизняні органи влади при здійсненні кримінального переслідування під час реалізації кримінальної відповідальності мають повноваження, окреслені межами внутрішньої (національної) кримінально-правової юрисдикції. Зважаючи на необхідність дотримання засад поваги державного суверенітету інших держав їхні працівники не можуть (і не мають права), керуючись внутрішнім законодавством України, виконувати на території іноземної держави дії, спрямовані на охорону правопорядку, розкриття злочинів, збирання доказів, затримання осіб, застосування покарань тощо [3, с. 174].

Перелічені вище чинники виводять проблеми організації реагування на злочини за межі внутрішніх інтересів нашої держави та вимагають від України вживати адекватні змінам криміногенної картини світу заходи як на рівні національної правової системи, так і на міжнародно-правовому рівні. В таких умовах все більш актуальними стають питання розвитку міжнародного співробітництва України в «антикримінальній» сфері.
Ці завдання мають спільно вирішувати всі суб'єкти владних повноважень як ті, які відповідають за нормативне забезпечення кримінальної політики України (парламент держави), так i ті, що здійснюють іï практичну реалізацію (вітчизняні органи кримінальної юстиції) [4].

У спеціальній літературі питання міжнародного співробітництва, зумовленого спільними потребами підтримання правопорядку, обговорюються досить часто. Однак його загальне визначення ще й досі $\epsilon$ дискусійним. Слід звернути увагу на те, що для формулювання відповідних дефініцій часто користуються категорією «міжнародне співробітництво в боротьбі зі злочинністю». В одних випадках їі визначають як співробітництво із забезпечення захисту особи, суспільства, держави, міжнародного співтовариства від злочинних діянь, суспільна небезпечність яких вимагає об'єднання зусиль кількох держав. В інших це співробітництво розглядається як складна система відносин, що включає злочинність як об'єкт цілеспрямованого впливу держав у боротьбі з нею, узгоджену політику, договірно-правову основу та внутрішнє законодавство, правозастосовчу й організаційну діяльність суб'єктів співробітництва з попередження злочинності, кримінально-правову боротьбу з нею та виконання кримінальних покарань при дотриманні встановлених правил поводження з правопорушниками [5, с. 14-16].

Як слушно вказує М.В. Буроменський, співробітництво поширюється на процеси уніфікації кримінального, кримінального процесуального, пенітенціарного законодавства, на надання міждержавної правової допомоги у кримінальних справах, на процеси формування міжнародного кримінального права [6, с. 738739]. Тому правова основа діяльності держави, міжнародної спільноти і їхніх представників у цьому напрямі $\epsilon$ комплексною. Як вважають деякі автори, вона включає положення як міжнародного кримінального права, так і норми внутрішнього кримінального та пов'язаного з ним законодавства [7, с. 43]. Слід зазначити, що міжнародне співробітництво з питань протидії злочинності не слід ототожнювати з міжнародним кримінальним правом, оскільки вони $є$ самостійними й рівнобіжними векторами розвитку міжнародно-правового співробітництва з правових питань [8].

Норми міжнародного кримінального права уособлюють волю світової спільноти, спрямовану на забезпечення процесів міжнародного співробітництва. Якщо держава з якихось причин ігнорує ці норми, це означає, що вона не бере участі у глобальній взаємодії з приводу зазначених злочинних посягань. Хоч фахівці часто конструюють відповідні дефініції крізь призму категорії «боротьба зі злочинністю», але понятійний апарат сучасних наук кримінально-правового циклу в сфері, яка стосується впливу на злочинність, відрізняється значним розмаїттям.

У науковому обігу перебувають також поняття «боротьба зі злочинністю», «попередження злочинності», «контроль над злочинністю», «правоохоронна діяльність» та низка інших. При цьому боротьба зі злочинністю розуміється як реакція суспільства на окремі злочини з метою стримування злочинності як явища за допомогою застосування кримінально-правових заходів впливу до осіб, які вчинили конкретні злочини [9, с. 4]. Міжнародна «антикримінальна» взаємодія і співпраця вказаними цілями і застосуванням зазначених засобів 
не обмежується. У сучасному світі вона розвивається і в сфері розробки нормативно-правових актів, і в поліцейській сфері, і в пенітенціарній. Тому говорити про «міжнародну боротьбу зі злочинністю» - звужувати реальний зміст цієї діяльності. Більш точно ії позначає категорія «міжнародне співробітництво у протидії злочинності». Вона краще відповідає європейському підходу до такого виду діяльності, оскільки дозволяє охопити як мінімізацію протиріч і факторів, які породжують злочинність і сприяють їй, так і скорочення окремих видів злочинів, а також адекватні заходи реагування на вже вчинені злочини [10, с. 163].

Понад півстоліття (починаючи з першого Конгресу $\mathrm{OOH}$ з попередження злочинності та поводження з правопорушниками, який відбувся в 1955 році в Женеві) у світі функціонує глобальна система боротьби зі злочинністю, яка включає головні органи ООН, їі спеціалізовані установи та міжнародні організації, а також міжнародні регіональні організації по боротьбі зі злочинністю, міжнародні та національні судові системи, правоохоронні органи держав [11, с. 10]. У європейському регіоні міжнародне співробітництво з кримінально-правових питань координується Радою Європи, а також компетентними органами Євросоюзу (Європейською комісією, Радою $Є$ ) і створеними ними наднаціональними правоохоронними структурами (Європол, Євроюст). Зростає інтенсивність міжнародних контактів і на рівні національних правоохоронних органів (міжвідомчого співробітництва).

Структура міжнародного співробітництва України в сфері запобігання злочинності може бути показана перш за все за напрямами (рівнями), які дозволяють виділити двостороннє, регіональне та універсальне співробітництво [12, с. 184-189]. На двосторонньому рівні воно забезпечується договорами між Україною та окремими іноземними державами про взаємну правову допомогу, видачу злочинців, передачу засуджених осіб для відбування покарання (наприклад, це договори України про правову допомогу та правові відносини в цивільних і кримінальних справах із Республікою Грузія, з Естонською Республікою, з Республікою Молдова, з Республікою Польща). Такий формат взаємодії дозволяє максимально врахувати інтереси кожної сторони з конкретної проблеми [13, с. 11].

Висновки. Надійною гарантією належного функціонування європейського простору юстиції, свободи та безпеки (створення умов для ефективної міжнародної правоохоронної діяльності) $\epsilon$ забезпечення необхідного рівня правопорядку не лише на території кожної окремої держави, але й усіх держав загалом.

Характерною ознакою спільного простору юстиції, свободи та безпеки $\epsilon$ необхідність забезпечення гармонійного поєднання двох його аспектів: зовнішнього та внутрішнього. Внутрішній аспект цього простору передбачає об'єднання зусиль правоохоронних органів держав на забезпечення внутрішньої безпеки та під- тримання правопорядку на території усього співтовариства, створення низки спеціалізованих органів (інституцій), діяльність яких має бути спрямована на сприяння роботі міжнародної системи запобігання злочинності.

\section{Література}

1. Голик Ю.В., Коробеев А.И. Преступность - планетарная проблема. (К итогам XI Конгресса ОOH по предупреждению преступности и уголовному правосудию). СПб : Изд-во «Юридический центр Пресс», 2006. 215 с.

2. Устав Организации Объединённых Наций и Устав Международного суда. URL: http://zakon.rada.gov.ua/ laws/show/995_010 (дата звернення: 18 грудня 2019 року).

3. Зозуля $\bar{\epsilon}$. Міжнародне співробітництво в боротьбі зі злочинністю як історико-правове явище. URL: http: / / www.experts.in.ua/baza/analitic/index. php?ELEMENT_ID=41902 (дата звернення: 24 грудня 2019 року).

4. Didkivska G.V., Matkevych Y.Y. Causes and conditions of smuggling in Ukraine. Науковий вісник Ужгородського національного університету. Серія: Право. 2019. № 58. Tом 2. C. 75-79.

5. Черкасов Р.А. Проблемы международного сотрудничества в области борьбы с организованной преступностью. Воронеж : ВГУ, 2003. Вып. 1. 250 с.

6. Буроменський М.В. Міжнародне співробітництво України у сфері запобігання злочинності та боротьби з нею. Правова система України: історія, стан та перспективи: у 5 т. Х. : Право, 2008. Т. 5: Кримінально-правові науки. Актуальні проблеми боротьби зі злочинністю в Україні. С. 738-739.

7. Амранов Г.И. Место и роль уголовного права при реализации международного сотрудничества государств в борьбе с преступностью. М. : Моск. гос. акад. приборостроения, 2003. 150 с.

8. Буроменський М. Деякі судження про поняття міжнародного кримінального права. Вісник Академії правових наук України. 2003. № 2-3. С. 359-370.

9. Литвинов О.М. Організаційні засади функціонування системи протидії злочинності. Вісник ХНУВС. 2007. Вип. 39. С. 37-45.

10. Шостко О.Ю. Теоретичні та прикладні проблеми протидії організованій злочинності в європейських країнах : Автореф. дис. д-ра юрид. наук. Харків, 2010. 45 с.

11. Новіков О. Світовий досвід функціонування спеціалізованих антикорупційних органів. Ефективність державного управління : збірник наукових праць. 2015. Вип. 43. URL: http://www.lvivacademy.com/vidavnitstvo_1/edu_43/ fail/8.pdf (дата звернення: 24 грудня 2019 року).

12. Мартин Г.П., Шуман Х. Западня глобализации: атака на процветание и демократию. М. : Альпина, 2001. 335 с.

13. Войціховський А.В. Міжнародне співробітництво у боротьбі зі злочинністю як пріоритетний напрям зовнішньої політики України. Право і безпека. 2010. № 3. С. 10-15.

Дідківська Г. В., кандидат юридичних наук, доцент, професор кафедри кримінальногои права та кримінології

Університету державної фіскальної служби України 